\title{
The Culture of Consumption as a Consequence of the Economic Process in the Context of Changes in the European Union
}

In research on cultures of the turn of the millennium, there are metaphors related to free market phenomena, such as: culture supermarket, temple of consumption or even marketization of the subject. We can clearly see here finding links between a certain part of cultural phenomena, which are free market processes or, in other words, the introduction of processes related to the liberalization of production processes and their impact on other cultural processes. It can be noticed that culture researchers often talk about processes called the culture supermarket. These considerations are aimed at finding the answer to the question whether we are not dealing more with the culture of the supermarket. The difference is that the culture supermarket is a place where an individual consumes culture like other goods, comes and requires as a customer (obviously simplifying this process to a large extent), while by supermarket culture we mean here the transfer of processes conditioning the operation of free market mechanisms to other cultural spaces. It is worth emphasizing that the economic changes we recall here can be observed on the examples of countries moving from a planned economy to a free market economy. It is about the transformation of a society that had no chance of being a consumer, which resulted from a lack of goods in a society of excess goods that are not available to everyone. Thus, we can compare what the researchers of Western culture wrote about consumer society, as well as economic and cultural processes, which took place in Central and Eastern Europe, i.e. in Poland or the Baltic countries, or a little later in the countries of the border between Europe and Asia, i.e. in the Caucasus in the countries, which seek to deepen relations with the Union in Azerbaijan, Armenia and Georgia.

Through comparative analysis of discourse related to the description of economic free market processes and discourses related to cultural processes, we want to find a research perspective on the mutual influence of these cultural processes. However, we do not intend to present the economic process as the only condition for other cultural processes. Rather, it is about orienting research into processes that would allow to build tools for predicting cultural changes under the influence of economic changes. Since it is possible to describe and introduce rules of the free market where they were not binding and foresee the next stages of achieving international competitiveness, then one can also point to changes in other areas of culture forced by this process.

Alan Aldridge, dealing with cultural processes related to marketization, states that "The sense of the metaphor of the invisible hand lies in paying attention to the capital 
significance of the immeasurable consequences of economic actions: individual, egoistic interests are capable of producing social cooperation" (Aldridge, 2006, p. 24). When we think about cooperation, we usually think of a situation where everyone consciously helps others in activities caused by a strong sense of community. "However, it does not happen to us," continues the author of the Market, "think of cooperation as something impersonal and immeasurable, although that is exactly how markets usually operate" (Aldridge, 2006, p. 24).

Therefore, you can summarize the Aldridge's words: The "Invisible hand" is irrational cooperation of individually shaped, selfish interests. This means that it is the emergence of a certain order from the chaos of incomprehensible connections. The question arises, who are they incomprehensible to? After all, the market is a place of competition that is supposed to lead to economic growth of a given area or entity, and this is happening. Even if they are impersonal processes, they have a specific impact on the entities participating in them. International competitiveness is defined as the ability of a country or a company to create greater wealth than competitors on the world market. The competitive ability of a given country is the result of transforming the country's resources either existing (e.g. natural resources) or generated (e.g. infrastructure, human capital) through processes (e.g. production) into economic effects, which are then verified in competition on international markets (The World Competitiveness Report, 1994, p. 18).

International competition consists in activating economic mechanisms that are to lead to economic stimulation. Capital investments are among the basic tools of this stimulation. When E. Cyrson analyzes the phenomenon of foreign direct investment (FDI), he notes that "the essence of FDI consists in the 'production package' moving across the borders, which consists of capital as well as the accompanying productive forces" (Cyrson, 1981, p. 157). The productive forces include technologies, procedures and processes related to marketing and management.

The condition of FDI inflow is the possibility of multiplying capital, but simultaneously, the same process enlivens a given space (e.g. country), which causes an increase in earnings, purchasing power, and thus the welfare involved in this process.

Four basic stages of economic development (country's competitiveness) can be distinguished:

1) Stage controlled by production factors (work, raw materials);

2) Investment driven stage (foreign direct investment);

3) Innovation driven stage (research plus development);

4) Welfare stage (M. Porter, 1990, p. 41).

The first stage is labor and resource-intensive, which means that the resources of a given region are used and they bring income. The second stage is definitely capital intensive. External investments allow the construction of infrastructure, introduction of new technologies and manufacturing processes. The next, third stage develops based on a significant share of qualified work and technologies resulting from the development of the region, employee education and the possibility of creating innovation.

Looking at these stages, we can see that in the first phase employees are used as cheap labour in relation to other regions; in the second phase, due to investments and greater efficiency of work, their wealth increases, which causes the awakening of the 
desire to own goods that they produce. In the case of complementarity of international trade and FDI, the inflow of foreign capital causes a significant increase in demand for imported goods, both investment and consumer ones (Koima, 1985, pp. 135-145). In the third stage, employees develop their skills. Factors increasing the effectiveness of the described process are: higher education and training, goods market effectiveness, labor market efficiency, developed financial market, market size and the ability to benefit from existing technology (Porter, 2001, p. 198).

Let us emphasize again, the first stage is the stage of obtaining initial funds. Employees whose work is so cheap that it stimulates the transition to competitiveness, initially work to have the resources necessary for survival. However, when more and more people work in the family, which is caused by the inflow of capital and the opening of new enterprises, the wealth of the employed increases, which means that they can afford other goods than those necessary for survival.

By producing goods, employees see that they could have them, and ways to stimulate consumption, for example loans, give them the chance to buy them, which so far few people could afford. An extremely interesting study of this type of economic changes was presented in the work International competitiveness of the Baltic States by Małgorzata Runiewicz (Runiewicz, 2006). The author not only presents theoretical assumptions but also taking advantage of very multifaceted material about Lithuania, Latvia and Estonia presents the economic changes of these countries and the effects over the next decade. The whole process was quite similar to that in Poland, from shock therapy, GDP reduction, inflation to economic growth, while this increase in the Baltic States was significantly faster. As we can see, coming back to the transformation of other areas of culture, the "invisible hand" socially creates reality (See: Berger, Luckmann, 1983) in which we live, by definition it becomes social in the sense that it must be consolidated by growth-oriented social norms.

Daniel Bell notices a negative dimension in this phenomenon. "The tragedy of classical liberalism as well as utopian socialism," he writes, "was the belief that people in every generation and every new social contract can start from scratch, reject the past, and rebuild their institutions. People can change themselves and society within certain limits, but knowledge of their own power must be accompanied by awareness of its limitations. This is the oldest and most enduring truth about the human condition, if it still has a human form" (Bell, 1998, p. 319). It is the liberal "truth" about the lack of restrictions that is an important disadvantage or even an obstacle on the way to finding one's own place in society, which means that individual freedom cannot find its realization. The individual believes that he is free, but he does not know what this freedom can be, moreover, taking advantage of it always leads to the unknown.

This way of looking at the society that lives in times of growth is only a mainstream socio-cultural change in which everyone does not have to participate, and in addition, participants have the freedom to participate. The message, however, framing the ways of participating in culture, which is interspersed with advertising and other ways of drawing attention to products, is so ubiquitous that it seems obvious, which implies conformist behavior. Conversely, rapid changes, especially in the value system, and the exchange of one system for another, can lead to anomy and various forms of dealing with it. You can accept new goals and ways to pursue them, but you can also not 
apply them. Each thesis outstrips the antithesis, which means that every new system is also a contribution to conflicting views.

Let us return, however, to the perception of the socio-cultural space shaped by the economic process that is to lead society to economic growth. In the case of the free market and the struggle for growth, basic needs are taken into account, without going into the rationality of the process for the individual. And this means that economic activities are focused on meeting the needs of the individual, provided that they are consistent with the needs of market development. Consumer behavior is the result of many motives, among which the following can be distinguished depending on the adopted criteria: - biological motifs resulting from the physical properties of the body, - social motifs related to the social environment, - rational (economic) motives referring to a thoughtful, rational purchase of goods, - emotional motifs related to spontaneous, impulsive actions under the influence of the moment, emotions, mood (Woś, Rachocka, Kasperek-Hoppe, 2004, p. 53). All the motives of human behavior can lead to the purchase of goods that promise to satisfy desires.

G. Belch and M. Belch define consumer behavior as a process and activity of people who engage in searching, choosing, purchasing, using, evaluating and disposing products and services to meet their needs and desires (Belch, Belch, 2011, p. 105). From an economic point of view, consumer behavior is understood as the way consumers make a choice about how to spend their income (Black, 2008, p. 552), obviously based on their own motives.

In the literature on consumer behavior, the need is most often defined as: "a state of lack of something and, at the same time, a factor triggering the function of a motive to act towards a proper change of this state" (Hołub, Perenc, Rosa, 1997, p. 85). The need arises when a person becomes aware of the gap between the desired state and the actual state realized by the individual (the so-called motivational tension arises) (Światowy, 2006, p. 45).

The product purchase process is always initiated by the needs of customers. Realizing the need may be the result of (Fundamentals of marketing, 1998, p. 32): noticing the lack of a product (e.g. washing powder packaging is ending), obtaining information about a new product and its usefulness by the consumer (e.g. from an advertisement, press article or from friends), revealing new needs - related to e.g. a new job (elegant clothes), improving the material situation - there are free funds that can be spent on unmet needs (e.g. buying a dishwasher or home theater), changing expectations regarding the product used so far (e.g. buying a new TV, because the old one cannot receive digital TV). It can therefore be concluded that there are simply infinite needs.

As part of marketing, it is assumed that the current level of consumer consumption is usually below the desired one (Ostrowska, Gracz, 2013). This is due to the fact that each purchase decision is limited by the capabilities of the unit (especially financial ones). It should therefore be assumed that man always feels more needs than he is able to satisfy. It is even a natural state in terms of marketing and economic processes.

However, it seems that in some cases free market laws do not allow the thought that an individual is able to impose self-restrictions and be satisfied with it. How does it look like in the case of pro-ecological, religious or social behavior for the excluded? 
According to Adam Smith, as indicated by Z Bauman, individual exchange, in which everyone pursues his own interest, is the basis of freedom, satisfaction and mutual benefit; in a rational way, it is also a source of accumulation and wealth (Bauman, 2000, p. 288). However, according to Kant, public law should be procedural rather than substantive one; its "purpose is to define the rules of the game in which people can compete for what they want, rather than determining its results" (Bauman, 2000, p. 288).

In free market societies, economic processes try to appropriate the goals of human action in the sense that when this fails, transformation cannot take place. The goal of achieving competitiveness is paramount and it can be accomplished in various ways even by shifting accents.

Today, as some believe, we are dealing not with the market but with the consumer market. Tomasz Szlendak begins his book Supermarketization with the following words: "The capitalist culture of producers is transforming today, at a rapid pace, into a culture of consumers. Although it is a mental shortcut and a significant simplification, it is impossible not to notice that a momentous change is taking place at present, which can be compared to the one which decided about the emergence of a cultural formation called modernity" (Szlendak, 2004, p. 5). Does the change in emphasis transferred from the producer to the consumer mean weight being assigned here? Probably not. What is important is the central form of all phenomena. In the past it was impossible to imagine the market without those who manufacture products, today without those who buy them. This, of course, does not mean that you could ever imagine a market without both. However, just as the product was once an initial impulse, now it is believed to be an effect or rather a final element depending on the whim of the consumer, at least according to this concept. Strategic marketing is based on the fact that first it must be checked what the consumer might want, what they will buy if it appears on the market, and only then it should be produced.

Today we are dealing with a society not so much of producers as of consumers. This means that we are dealing with a consumer society. "Society is just becoming consumer society when consumerism is a massive phenomenon" (Schor, 1999, p. 217). This is the crux of today's market, the mass consumer market.

The consumer society is based on the continuous increase in consumer spending, and this increase is essential for the economic functioning of the system. Moreover, culture, ideology and morality develop in accordance with this economic order (although not without resistance - after all, religions, e.g. Catholicism, very often emphasize the fact that the ideology of consumption is definitely not their ideology). "Insatiability is becoming a common norm. Social and political stability remain dependent on the delivery of consumer goods" (Schor, 1999, p. 217). In the consumer society, all aspects of life depend on consumption. Let us add that the consumer society is the effect of addiction to consumption, which is a necessary stage of economic development. Therefore, if the society does not become the consumer society, it cannot count on economic growth that will allow it to join the richest societies. An important element of the competitiveness of countries such as Poland is the construction of the internal market. The state's competitiveness is not only about exports, it depends to a large extent on internal sales, i.e. building a consumer market. Foreign direct investment, i.e. 
the flow of money from more developed countries in the European Union, depends on the possibility of acquiring the labour market and the market of less affluent partners.

There may be some sympathies associated with investments, as was the case with Estonia and the Scandinavian countries. However, if we look closely at the processes themselves, then the increase in Estonia's competitive opportunities at a certain moment causes closer cooperation with other countries, in particular Germany (See: Runiewicz, 2006).

Alan Aldridge points out that this is an important aspect of the market, for example in Giddens's view, for whom "the contradiction between dogmatic faith in the market and unwavering attachment to traditional values and social institutions, especially the family, is the weakest point of the neoliberal thought. The free play of market forces destroys traditional structures instead of supporting them. Conservative values do not derive from market principles, but are arbitrarily imposed on them" (Aldridge, 2006, p. 138). The question is whether traditional values can win the fight against market values. Surely one can see social changes that indicate the evolution of traditional values, but it cannot be said that the market has won this fight and consumption has captured the subject's mind.

Certainly, the fight with specialists, "market followers" can only end with a change in consumer behavior, not a resurgence of subjectivity that chooses its attitudes.

According to Bauman: "Flexibility on the demand side means freedom of wandering in search of greener pastures, leaving debris and rubbish around an abandoned camp, because the locals still have to clean up; above all, however, it means neglecting everything that is not economically valuable. However, what appears to be elastic on the demand side becomes the hard, cruel and ruthless fate of those on the supply side" (Bauman, 2000, p. 123). Not only is there little choice here, but also economic constraint, which directs some towards consumption, places others where they can be exploited and enslaved.

The problem is that both are once on the demand side and another time on the supply side, and this means that the choice would be limited only to soliciting the goods and selling themselves as the goods. This point of view can be discussed, but it cannot be accepted. Bauman himself does not seem to be such an extreme pessimist.

However, it follows from the above considerations that the consumer may not only be imprisoned within the market as the one acquiring its values, but also as the one who sells his work, and thus gives away more than he would like for the "invisible hand of the market." Nevertheless, he is also the one who defies the market, whether as a capricious consumer who refuses to accept only what the market offers him, or as an entity also finding values outside the market.

The consumer consumes when he makes his own decision, it can be caused by some external factors, but he is always independent. Bauman says that the market is somewhat dependent on the consumer, even though the general rules that govern it are always the same. "[...] The same rules apply in all markets. First of all, the final destination of all goods intended for the market is for consumers to consume them. Secondly, buyers will want to get goods for consumption if and only if consuming them promises to meet their needs. Thirdly, the price that a potential consumer seeking satisfaction is willing to pay for the goods offered will depend on the credibility 
of this promise and the intensity of his need" (Bauman, 2009, pp. 16-17). However, it is the consumer who decides whether a good can meet the needs or whether it brings him closer to fulfilling his desires. Every consumer is an aware consumer, although not everyone manages to achieve what they are seeking.

Man as a consumer is introduced to the world of financial value, which is supposed to replace all other values. While we must state that changing attitudes and recognizing other values depends on human decisions, it should be noted that if new values are universally present and prompted as basic, there will be a slow change in human behavior. It can be expected that interpersonal relationships will acquire a financial dimension. The ordinary exchange of gifts described in various dimensions and cultures is transformed into one type of exchange. This new dimension is the conversion of each value into market value. You can even recalculate human life and the possibility of saving it. After all, we need to calculate whether we can afford to give some medicine to a dying patient.

Obviously, in the gift exchange system, the patient would probably also have to die because they would not find so many loved ones. The end result can thus be identical; what is changing is the very picture of the whole operation. In the world of a free market, it is automatically calculated whether the medicine can be refunded or what insurance covers. In the case of exchange of gifts, we do not have a transparent conversion of human life into another value, especially the financial one.

Therefore, change is not about forcing a man into something, nor is it about submitting a man to a free market that affects him with some undefined secret force. Everything is a smooth process that slowly replaces lasting relationships with financial relationships. It should be emphasized that financial relations here are the answer to the deepest human need, i.e. being safe. Money that allows you to move your work over time (today I work and do not spend when I cannot work, I spend what I have earned) is a measure and a guarantee of security.

For example, you can set a pre-marital intercession that will accurately calculate who brings what and what he/she can get out of marriage. The situation changes only when it comes to complete and unconditional entrustment to the other party as there is no entrustment in this case, and it means that the whole family will not have to guard the success, because everyone is legally and financially secured. Thus, we are able to determine the extent to which we will be responsible for other people.

One can estimate the price of the educational process that once took place between the master and the student, and was not only about teaching skills and acquiring knowledge, but also about the relationship that remained for many years, and even after the master's death was present in his successor's life. When we determine the price, the relationship loses some of its dimensions. If I earned and paid, I owe myself that I could buy care and mentorship of this and not another person. I chose, I earned, I paid. At the heart of the process there is money and there are payers. It looks as if money was really the initiator and the ultimate sense of the whole process.

In this way, development is translated into measurable financial value, which means that it is inseparably connected with its flow. Thus, it can be calculated exactly how many hundreds of thousands of zlotys or dollars has to be spent, for example, on education for children to succeed. And here again, success is most easily determined 
by measurable financial value, which can be expressed in the form of visible luxury goods. The trap is that hardly anyone achieving this kind of success will know that they can afford to raise a child. After all, he/she is aware of how much effort it will cost, how much time it will take to work, and this effort will not be immediately visible. If the child does not succeed, it will never be visible. In addition, when raising a child the financial contribution is not secure, there is even no way to sign a parental security contract.

The above reasoning is not supposed to present how the process of thinking about family planning takes place, it can rather show a fairly rational course of such thinking, even if it is not conscious. After all, every economic process, i.e. based on a financial relationship, is to lead to satisfaction, and in the example above it is difficult to diagnose whether it is possible to achieve.

In his book, Chances of Ethics in a Globalized World, Zygmunt Bauman dealt with the problem of distributing tensions that affect the individual, simultaneously showing how the individual perceives the world. "It seems likely (although the jury is still deliberating) that consumers - when they are subject to the logic of commodity markets and must rely on their own choices - perceive the distribution of power between the principle of pleasure and the principle of reality exactly the opposite. Now it is the 'principle of reality' that must defend itself; at every step, it is forced to retreat, selflimit and return the field in the face of subsequent acts on the part of the 'principle of pleasure" (Bauman, 2007, p. 34). In other words, it does not matter what reality we deal with, whether it is reality or not. It is important whether we feel pleasure or not. The world has ceased to be the world just because it exists. It is real when it provides the right amount of pleasant experience. What does it mean? Nothing more than the fact that the lack of pleasure is emptiness, emptiness felt as something that is not there or the space of lack of satisfaction, and thus a place where we touch non-existence. The "ontology" of the consumer says clearly: what is pleasant exists, what does not provide pleasure, does not exist. Distortion of tensions, transferring the accent from what exists to what provides the right stimuli, does not seem so abstract. Where there are no stimuli, it is difficult to discover anything, where there is no right stimuli, the same thing happens - this is the easiest way to summarize this problem. Bauman certainly does not conclusively decide whether it really happens, but shows a certain path that some - as you can presume - have already chosen.

As we can see, there have been major changes in social life. "People in power in a consumer society have apparently discovered and turned to their advantage that little can be gained from preserving hard and lasting 'social facts' that seemed inviolable in the time of Émil Durkheim, while focusing on the principle of pleasure, which guarantees infinite opportunities for development, promises infinite commercial profits in the long run. The clear and ever-growing 'softness' and flexibility of the 'social facts' of the society of liquid modernity allows us to free the search for pleasure from old restrictions and open them completely to market use" (Bauman, 2007, p. 34). Pleasure, becoming the determinant of the world, makes the world open to new ways of perception, but also to new behaviors. Pleasure becomes a mechanism that releases market opportunities, so that an individual can become a seller and buyer of market goods. Pleasure and consumption go hand in hand. 
It can be summed up in the words of Zygmunt Bauman: "The history of consumerism is a story about questioning and rejecting subsequent 'hard' barriers that limited the freedom of fantasy or, in the language of Sigmund Freud, covered the principle of pleasure to the size dictated by the "principle of reality"' (Bauman, 2005, p. 22). Today, the principle of pleasure is not so much discovered, which is the essence of all consumer behavior. Cognition of reality takes place through pleasure. It is pleasure that gives voice to what surrounds the consumer as if the world could be absorbed by the individual in the act of pleasure of learning.

One can refer to Fromm at this point: "The attitude that decides about the nature of consumerism", he says, "consists in the desire to swallow the whole world. The consumer is an eternal suckling, screaming for a bottle. This is clearly seen in pathological syndromes such as alcoholism and drug addiction" (Erich Fromm, 2003, pp. 69-70).

Fromm is talking about addictions that are the reason for non-compliance with social obligations. Today, anorexia, bulimia, compulsive buying, and more can also be mentioned. Pathologies are expanding, but also the approach to consumption itself acquires such pathological features. The consumer only wants pleasure, and when he gets it, he wants to repeat everything again. On the one hand, it is difficult to talk about addiction, but on the other - if all needs are met in one way and other ways are not allowed to speak as if they did not exist or were not important - it is difficult not to notice the similarity. The consumer, of course, may not be addicted, but consumption itself seems to use the mechanism of addiction, and the ideal consumer seems to be the incapacitated entity by buying goods for the constant rebuilding of transient satisfaction.

Referring to Fromm, his words can still be recalled: "[...] consumption is the only form of ownership, perhaps the most important in today's prosperous societies. Consumption has ambivalent properties - it frees you from anxiety, because what you have cannot be taken away anymore, but at the same time it requires from you to consume an increasing portion, because already consumed goods quickly lose the property of quenching thirst. A modern consumer could use the motto: 'I am what I have and what I consume"” (Erich Fromm, 2003, p. 70).

Not only what is outside is limited to consumer goods, but also the individual becomes someone through possession, like an alcoholic who becomes himself (in his opinion) only when he drinks his first glass as otherwise he feels insecure and uncomfortable.

Fromm's criticism seems to be very harsh. However, what Fromm claims when diagnosing society in the second half of the $20^{\text {th }}$ century is, according to economics, the ideal state of a society seeking international competitiveness.

If we analyze the descriptions of socio-economic changes in countries such as Poland, the Baltic States or the Caucasus, it turns out that their path to increase economic competitiveness is similar. It is associated with market changes but also a cultural change in a broader context. This means that the processes in developing countries in the European Union are similar to anywhere in the world where society is moving towards free market processes.

A hypothesis can be made: the individual is free, but as Kant has already noted, in the world of thought; freedom, however, does not exist in the world of phenomena. 
This hypothesis developed for societies that introduced a free market would be: the individual in the consumer society is free in the world of his thoughts but in the world of market phenomena he is subject to independent processes.

Let us add, however, that social phenomena are conditioned to a large extent by the world of thinking individuals. Therefore, the basic question is not: is the above hypothesis true because it can be said with certainty? The question is rather how fast and how much influence individual thinking can have on the processes of transformation of social processes.

\section{Bibliography}

Aldridge A. (2006), Rynek, Sic!, Warsaw.

Bauman Z. (2000), Globalizacja, Państwowy Instytut Wydawniczy, Warsaw.

Bauman Z. (2009), Konsumowanie życia, przeł. Monika Wyrwas-Wiśniewska, Wydawnictwo Uniwersytetu Jagiellońskiego, Cracow.

Bauman Z. (2005), Konsumując życie, w: Konsumpcja - istotny wymiar globalizacji kulturowej, pod red. A. Jawłowskiej, M. Kempnego, Wydawnictwo IFiS PAN, Warsaw.

Bauman Z. (2007), Szanse etyki w zglobalizowanym świecie, Wydawnictwo Znak, Cracow.

Belch G., Belch M. (2011), Advertising and Promotion: An Integrated Marketing Communications Perspective, McGraw Hill, New York.

Bell D. (1998), Kulturowe sprzeczności kapitalizmu, PWN, Warsaw.

Berger P. L., Luckmann T. (1983), Społeczne tworzenia rzeczywistości, PIW, Warsaw.

Black J. (2008), Stownik ekonomii, PWN, Warszawa.

Cyrson E. (1981), Korporacje międzynarodowe. Prawidłowości ekspansji zagranicznej, Warsaw.

Fromm E. (2003), Mieć czy być?, przeł. J. Karłowski, Dom Wydawniczy Rebis, Poznań.

Giddens A. (1999), Trzecia droga. Odnowa socjaldemokracji, Książka i Wiedza, Warsaw.

Hołub J., Perenc J., Rosa G. (1997), Podstawy marketingu, WN US, Szczecin.

Koima K. (1985), Toward a Theory of Industrial Restructuring and Dynamic Comparative Advantage, "Hitosubashi Jurnal of Economics", no. 269.

Ostrowska I., Gracz L. (2013), Młodzi nabywcy na e-zakupach, Agencja Wydawnicza Placet, Warsaw.

Podstawy marketingu (1998), pod red. J. Karwowskiego, Wyd. ZSB, Szczecin.

Porter M. (1990), The Competitive Advantage of Nations, London.

Porter M. E. (2001), Porter o konkurencji, PWE, Warsaw.

Runiewicz M. (2006), Międzynarodowa konkurencyjność państw nadbaltyckich, Wyższa Szkoła Przedsiębiorczości i Zarządzania, Warsaw.

Schor J. B. (1999), The Overspent American, Why We Want What We Don't Need, Harper Perennial, New York.

Stownik ekonomii (2008), Wydawnictwo Naukowe PWN, Warsaw.

Szlendak T. (2004), Supermarketyzacja. Religia i obyczaje seksualne młodzieży w kulturze konsumpcyjnej, Wydawnictwo Uniwersytetu Wrocławskiego Sp. z o.o., Wrocław.

Światowy G. (2006), Zachowania konsumentów. Determinanty oraz metody poznania i ksztaltowania, PWE, Warsaw.

The World Competitiveness Report 1994 (1994), World Economic Forum, Lausanne.

Woś J., Rachocka J., Kasperek-Hoppe M. (2004), Zachowania konsumentów - teoria i praktyka, Wydawnictwo Akademii Ekonomicznej w Poznaniu, Poznań. 


\section{Summary}

In the article, through a comparative analysis of the discourse related to the description of economic free market processes and discourses related to cultural processes, we are looking for a research perspective that allows to examine the mutual influence of these cultural processes.

If we analyze the descriptions of socio-economic changes in countries such as Poland or the Baltic countries, it turns out that their path to increase economic competitiveness is similar. It is associated with market changes but also a cultural change in a broader context.

Thus, one can hypothesize: the individual is free in the world of thought, however, in the world of phenomena, freedom does not exist. This hypothesis developed for societies that introduced a free market would be: the individual in the consumer society is free in the world of his thoughts but in the world of market phenomena he is subject to independent processes.

Key words: free market, consumption, culture, consumption culture, consumer society

\section{Kultura konsumpcji jako konsekwencja procesu ekonomicznego w kontekście przemian na terenie Unii Europejskiej}

\section{Streszczenie}

W artykule poprzez analizę porównawczą dyskursu związanego z opisem ekonomicznych procesów wolnorynkowych i dyskursów związanych z procesami kulturowymi szukamy perspektywy badawczej, pozwalającej badać wzajemny wpływ tych procesów kulturowych.

Jeżeli przeanalizujemy opisy przemian społeczno-gospodarczych, krajów takich, jak Polska czy kraje Nadbałtyckie, okaże się, że droga ich do zwiększenia konkurencyjności ekonomicznej jest podobna. Wiąże się ona ze zmianami rynkowymi, ale także przemianą kulturową w szerszym kontekście.

Można więc postawić hipotezę: jednostka jest wolna w świecie myśli jednak w świecie zjawisk wolność nie istnieje. Hipoteza ta rozwinięta na społeczeństwa, które wprowadziły wolny rynek brzmiała by: jednostka w społeczeństwie konsumpcyjnym jest wolna w świecie swoich myśli, lecz w świecie zjawisk rynkowych podlega niezależnym od niej procesom.

Słowa kluczowe: wolny rynek, konsumpcja, kultura, kultura konsumpcji, społeczeństwo konsumpcyjne 
